\title{
Lexical Expansion in Marginal Aids: A Study on Translating Cultural Loaded Implicit Meaning
}

\author{
Seyed Alireza Shirinzadeh \\ Faculty of Translation Studies, School of Languages, Literacies \& Translation, Universiti Sains Malaysia \\ Email: alireza.shirinzadeh@gmail.com \\ Tengku Sepora Tengku Mahadi
}

Faculty of Translation Studies, School of Languages, Literacies \& Translation, Universiti Sains Malaysia

\section{Doi:10.5901/mjss.2014.v5n20p2423}

\section{Abstract}

This study investigates some areas in translation that are parts of the cultural background knowledge in the source texts. As the target text readers do not share the same background knowledge with the readers of the source text, in translation, some information should be added for making the target text more understandable for its readers. This study is based on Nida's (1964) and further Nida and Taber's (1982) addition and/or expansion theory. The researchers seek to see what the translator, Rehatsek (2004), did in translating Golestan into English regarding cultural loaded implicitation. The study showed that the translator used the lexical expansion strategy in marginal aids and added eighty two cases of footnote in his translation for conveying this kind of implicitation.

Keywords: addition; cultural loaded implicitation; explicitation; lexical expansion; marginal aids

\section{Introduction}

There are some important factors behind the act of translation that affect the process of translating. Authors while writing their own works, whether a poet creating a poem or a literary scholar writing a novel or a journalist an article for a newspaper or a scientist a scientific article, take some information for granted. This is because they work on the assumption that they share the same world knowledge and cultural background with their readers. This state of conscience does not cause any harm as long as there is a mutual understanding and communication among the authors and their readers. However, it can prove problematic when translation or interpretation comes on stage. Translators or interpreters cannot afford to overlook this actuality since readers of translations or audience of interpretation will not have similar world and cultural knowledge as the original text readers or the source speakers. Besides, having to move messages from one language to another, translators and interpreters will frequently be faced with words or expressions in the source texts or languages that are loaded with implicit information; this kind of information as Pederson (2011) states belongs to the encyclopedic knowledge of the source text readers. Consequently, this fact should always be kept in mind in translation of a text or interpretation of a speech.

Such gaps in information need to be addressed and covered; in short, sometimes, some information not directly stated in original texts needs to be added to the translations. These acts of providing extra information or these explicitations might come into view in the body of the translation itself if the flow and organization of the text or the stream of the discourse allows it. Some of these expansions might have syntactic or cultural causes due to the dissimilarities among languages. While syntax related differences can be accommodated within the body itself, culture-related differences may require additional information to be inserted in the form of marginal aids. The latter forms the interest of the current research presented in this paper which attempts to investigate the use of these kinds of expansion by translators to make their translation more understandable.

\section{Literature Review}

Terms that form the central discussion of this paper will be defined here in order to elucidate the research. We start by explaining what is covered by information here. 
Information consists of two types, namely implicit and explicit. According to Beekman and Callow (1986), explicit meaning is clearly mentioned by words and sentence structure, whereas implicit information is not clearly mentioned, but, in fact, can indirectly be understood from the text or context. They put forth a typology of implied meaning founded on context and culture. They believe that implied meaning in the source text (ST) has three types, which a sensitive translator can detect:

a. Implicit meaning based on the immediate context

b. Implicit meaning based on the remote context

c. Implicit meaning based on the cultural context

While a profusion of the implied meaning of the ST is rooted in the immediate context, occasionally, it is necessary to get the exact meaning from somewhere else, i.e. the remote context. Moreover, implicit meaning rooted in the cultural context comprises four domains: "material objects, geography, religious and human culture" (p. 56). The focus of the present study is on this kind of implicit information, namely culturally implicit information which is not understood directly from the text but can be realized from the external context.

Another key issue of this study that should be discussed is the term expansion. Addition or expansion is one of the compensation strategies available to translators. With respect to it, Nida and Taber (1982: 4) put forth that "expansion is distribution of the semantic components over a number of different words. When we translate one word of the source language by several words in the target, we make expansion adjustment". In line with them, Larson (1984: 14) states that there is hardly ever an entire "match" between two languages. Consequently, for communicating similar meaning, one word of the source text recurrently needs to be rendered to some words in the receptor text. Undeniably, in a translation, expansion modification is a logical way of conveying the source text meaning. In view of that, Hjort-pedersen and Faber (2010) believe that translators have the tendency to add some information in the target text wherever they feel that the process of comprehending source text is hard.

Accordingly, Shiyab and Lynch (2006) state that translating a text is making an art work in a new language; this type of work requires the translator to be insightful and artistically resourceful. When there are areas in the unit of translation that are culturally implied and need to be clarified, the insightful translator should use extra explanation in his translation to remove ambiguities. Accordingly, Xiumei and Qinyan (2012) discuss adjusting the source text information in the target text. They mention that for doing so the translators are obliged to make use of some techniques of adjustments, among which is the technique of addition. In other words, they may add some implicit information to the target text during the process of translating.

In view of that, Ekpenyong (2010: 329) states that translation is trying to convey the "meaning of a word, phrase, clause, sentence or paragraph of one language into another language". Here, one should consider "the change of form at the level of semantic structure between both languages," wherein the translator may explicate some implicit information in the target text (p. 329). In the same way, Minacori and Veisblat (2010) mention that translation begins with a text in one language and finishes with a text in a new language which has identical meaning, but with only one difference, namely that some implicit information of the source text may become explicit in the target text and some explicit information of the source text may turn into implicit in the target text. In line with them, Hirsch (2011a, 2011b) has tried to explore the application of explicitation in rendering irony. The studies have indicated that translators have used additions in translating irony because of the fact that irony has implicit criticism which lies in the culture of the source text and should be explicated in the translation so as to compensate the cultural differences among different languages.

Culture is also regarded as background knowledge which is implicit in some words. Yang (2010) believes that translating cultural connotation is impossible due to dissimilarities among languages. Word-for-word translation is sometimes unfeasible because of the wide cultural gaps. Here, the translators' task is to lessen the losses. Thus, he may use a range of compensation techniques to facilitate the process of translating the implied cultural information. Accordingly, Zhongde (2003: 130) states that "addition, extension, break-up, incorporation, substitution, transposition, etc. may all fall under the category of compensation". Once a translator is not able to render some expressions word-for-word, he might apply one of these compensation techniques in order to better express the message of the original text. It is the case with cultural words which are heavily implied; thus, these compensation techniques might help translators cope with cultural differences between source language and target language (Leppihalme, 1997).

As mentioned earlier, cultural loaded implicit meaning is a significant problem which translators always face with. Accordingly, Hatim and Mason (1990: 223) state that translators should have "not only bilingual ability but also bi-cultural vision. Translators mediate between cultures (including ideologies, moral systems and sociocultural structures); seeking to overcome those incompatibilities which stand in the way of transfer of meaning."

In view of them, Pederson (2011) highlights the issue of cultural literacy and states that it is closely related to translation. Pederson further mentions that being proficient in one language does not mean being literate in the culture of 
that language and at the end being a professional translator. One cannot separate culture from language. Accordingly, he said that:

The language criterion is not very useful by itself, as the referents of most referring expressions could be said to be outside language. It is thus only when the referent is in some way cultural, i.e. only accessible through encyclopedic knowledge of a certain culture, that an extralinguistic culture reference is at hand (p. 48).

Yifeng Sun (2012) also discusses the issue of culture as background information that presents a challenge in translation. The issue of untranslatability strengthens an incessant need for readability, together with the need for pertinent cultural and cross-cultural issues in translation. It has great significance in literary translation. This kind of translation chiefly tackles the rendering of untranslatable issues. To enhance translatability, the inconsistency of translational conditions is directly dealt with. Therefore, it is essential to study various kinds of untranslatability which are limiting and forming translation. Besides, readability is achievable by using some techniques of adjustments which can create some sort of synthetic naturalness and intelligibility in translation (Yifeng Sun). In the case of translation, the important thing is meaning (Davidson, 2009). Everything that has meaning is translatable; the untranslatable texts are meaningless. Translators make use of different techniques for transferring the meaning to the target text. Their ultimate goal is preparing intelligibility for their readers.

Nida (1964: 226), talking about the techniques of adjustment used in the process of translating, advises that "why the translator does one thing or another" is not the matter of concern, but "what he does, in terms of additions, subtractions, and alterations" is important. He believes that these terms to a certain extent alter the image of the process of translation. As a matter of fact, his task is to choose in every case the "closest natural equivalent" (p. 226). However, sometimes, if one compares these equivalent forms in the target and original languages, it will be observed that translators may make use of such modifications like additions, subtractions, and alterations.

The techniques of adjustment are intended to create proper equivalents, not to be utilized as a justification for interfering with the original language meaning (Nida, 1964). For instance, the Hebrew text of Genesis evidently mentions that "Enoch walked with God" (p. 226). However, it sounds as if this book translator in the Septuagint has his own theological beliefs which did not accord with this kind of anthropomorphism. So, the translator has altered it to: "Enoch pleased God" (p. 226). The techniques of adjustment are not intended to rationalize such an alteration of the message of the original language; however, they are used to smooth the progress of its precise recreation in another form.

Nida (1964) states that the aims of these techniques are effectively in this manner: "(1) permit adjustment of the form of the message to the requirements of the structure of the receptor language; (2) produce semantically equivalent structures; (3) provide equivalent stylistic appropriateness; and (4) carry an equivalent communication load" (p. 226). To accomplish these aims, many minor modifications in form have to be applied; however, drastic alterations are not to be applied only for the benefit of editorial concerns or at the translator's envision. The translator's essential duty is to recreate "what he has been given, not to improve it," even once he feels he is able to do so (p. 226). Nonetheless, there are two conditions which need particular drastic kinds of alterations specifically: (1) once a close formal equivalent is totally not meaningful, and (2) once it has an incorrect meaning.

According to Nida (1964), the degree of applying adjustments relies chiefly on the readers of the target texts. For instance, if the translation readers are not familiar with the subject and have fairly little knowledge in understanding it, a higher extent of redundancy has to be applied in the translation. As a result, more adjustments are used. In addition, the type of the audience decides significantly that such adjustments should be used inside the target text or in additional clarifications such as marginal notes (Nida).

Nida and Taber (1982: 163) state that there is "a tendency for all good translations to be somewhat longer than the originals". However, it does not indicate that any long rendition is inexorably a good one. This fact only tries to say that in the translation process from one linguistic and cultural organization to a different one, unavoidably, translation will more or less turn out to be longer.

Nida and Taber (1982) argue that the proclivity towards greater length in translation is thanks fundamentally to the truth that the translator desires to state all of the original text information; besides, it is often obligatory for him as well to explicate in the target language the implicit information of the source text. This is due to the fact that the original text readers seemingly had the crucial and vital background to comprehend the message contents. Consequently, once the translator chooses forcibly to be relatively more explicit in the receptor text than in the original text, the rendition will be necessarily apt to have more length. 


\section{Method}

The present research is, according to Holmes (1972a), a product-oriented descriptive translation study, which aims to investigate the existing translation (cited by Baker in M. baker, 2004). This study is based on Nida's (1964) and further Nida and Taber's (1982) addition and/or expansion theory; here, specifically the use of lexical expansion in marginal aids or explicitly the usage of additions in footnotes is investigated. Therefore, via a descriptive method, the researchers have extracted and analyzed the occurrences of addition and/or expansion while investigating the Persian text and its English translation. In order to do the research, the researchers chose one of the prominent literary works in Farsi, that is, Golestan by Sa'di who is a famous literary figure in Farsi literature. The point in selecting this text is that it is integrated with culture loaded implied meanings. And, the English translation of Golestan by Rehatsek (2004) was selected as the target text. Forty one stories of Golestan were chosen randomly to be analyzed. The researchers studied the selected stories and their translation to analyze the cases of addition or expansion that were used in marginal aids. The unit of the analysis was the sentence. The researchers went through the selected stories and their translations sentence by sentence to investigate and extract the expansion cases that are evident in the translation of culture loaded implicit information. Then, the researchers started analyzing each of them and giving the possible reasons for their expansions.

\subsection{Theoretical framework}

The theoretical framework is based on Nida and Taber's (1982) notion of lexical expansion in marginal aids and Nida's (1964) notion of addition usage in footnotes as marginal notes. In the following, they are explained.

According to Nida (1964), there is a propensity for the translations to have more length than the source texts. This proclivity to greater length is thanks principally to the truth that the translator would like to transfer everything that exists in the source text; nonetheless, it is often necessary for the translator to explicate in the target text the implicit information of the source text, as the target text readers presumably do not have the vital background to grasp the message of the original text. Nida believes that the extent of utilizing additions is closely related to the addressees of the translations. Accordingly, if the target text addressees are not aware of the topic and thus cannot relate to the text, more addition techniques such as marginal notes and footnotes have to be employed in the translation.

Nida and Taber (1982) mention that in explicating the implicit information, the translator frequently adds information in the passage itself with no forcing of unnecessary tensions on the translation process. Conversely, information crucial for comprehending the message is frequently not particularly implicit in the text itself. This kind of information might simply belong to shared cultural background which is common among the readers in the original language. Such information would not be justifiably added into the text of a translation, however, has to be put in marginal aids, whether in the shape of glossaries, in which information concerning frequent expressions is collected in brief, or in marginal notes in the page in which there is complexity in comprehending (Nida \& Taber).

According to Nida (1964), once a literal or close translating brings about a meaningless word or incorrect understanding of the text, the vital adjustments are normally applied in the text. However, there are conditions wherein literal translations are relatively kept in the target text, and the necessary adjustments are clarified in marginal notes or footnotes. Sometimes, modifying the target text may bring abnormalities to the text in a way that the distance between the original and the receptor text in terms of culture and time cannot be preserved. In this case, having a literal equivalent in the translation and giving clarifications in the footnote is justifiable. Nida suggests that on the whole, in a translation, footnotes have two major tasks: first, explaining cultural and linguistic differences like clarifying opposing customs, explaining unfamiliar physical or geographical items, mentioning measures and weights equivalents, giving explanations about word plays, and providing extra information about proper names such as Rostam, Hormuzd, Eskandar, second, including data that might be normally helpful in comprehending the cultural and historical background of the text under study.

Such notes might be used in the page where the word or phenomenon is mentioned (Nida, 1964). In other cases, the content of these notes might be summed up in the shape of glossaries or tables, put at the end of the book. However, glossaries or tables are typically planned to assist somewhat special addressees. Some translations are available with fairly numerous notes. In these cases, they are typically categorized as commentaries. These commentaries are frequently used for translation of old texts. On the whole, translation is fairly considered as a solo performance, without identifying that a translation is typically the outcome of countless years' effort, for the period of that time both the translators and the readers of the translation have added broadly to the structure of the translation as the outcome of their personal experiences (Nida). Furthermore, especially in terms of religious books, translation is hardly considered as proper for always, since the texts have to be continually modified for serving the constant requests of an existing society. 
Therefore, it may need numerous additions.

\section{Data analysis and Discussion}

As a whole, eighty two cases of expansion were identified and analyzed by the researchers. In the following, quantitative results of investigating the expansions used in the target text for translating culture loaded implicit meanings of the source text will be mentioned in the table and then only a selected few instances are discussed due to space constraint. The present study revealed that the cases of marginal expansions have been related to five categories. In fact, the translator has applied the expansion strategies in marginal aids for translating the following items: personal names, geographical names, event's names, religious terms, mystical proper names. Table 1 shows their number and percentage.

Table 1. The Number and Percentage of Each Kind of Expansions

\begin{tabular}{lcc}
\hline & Number & Percentage \\
\cline { 2 - 3 } Expansions regarding personal names & 32 & 39.02 \\
Expansions regarding geographical names & 11 & 13.41 \\
Expansions regarding events' names & 8 & 9.75 \\
Expansions regarding religious terms & 29 & 35.36 \\
Expansions regarding mystical proper names & 2 & 2.46 \\
\hline Total expansions & 82 & 100.00 \\
\hline
\end{tabular}

As can be seen in the above table, 39.02\% cases of the expansion were found regarding the translation of implicit meaning existing behind some personal names. $13.41 \%$ of the expansions belongs to translating implicit meaning about geographical names. Explicating the implicit meaning regarding the names of the events includes $9.75 \%$ of the total expansions. Expansions used for rendering implicit meanings regarding religious terms and mystical proper names were $35.36 \%$ and $2.46 \%$ of the total, respectively.

\subsection{Instances}

\subsubsection{Translating personal names}

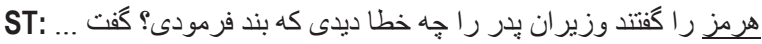
[hormoz] [rä] [goftænd] [væziräne] [pedær] [rä] [che] [khætä] [didi] [ke] [bænd] [færmudi] [goft]

TT: Hormuzd*, being asked what fault the vezires of his father had committed that he imprisoned them, replied ... *Not less than five kings of the Sasanian dynasty bore this name.

Using a footnote, the translator has clarified that the proper name "Hormuzd" is the name of a king. Thus, he has made his translation understandable for his readers. Indeed, Hormuzd is a well-known figure in the society of the source language; accordingly, source text readers fully know him, but the target text readers are not familiar with him. Thus, the translator has felt this lack of familiarity and has tried to expand his translation and express the fact of his being a king of Sasanian dynasty. He has duly made use of a footnote wherein he has clarified this fact for the target text readers. As a result, the translation readers have better understanding of the target text by studying the footnote. Therefore, it is a case of lexical expansion which was used as a marginal aid.

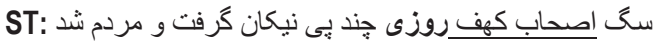

[sæge] [æshäbe] [kæhf] [ruzi] [chænd] [peye] [nikän] [gereft] [væ] [mærdom] [shod]

TT: The dog of the companions of the cave* for some days

Associated with good people and became a man

*In the Quran, Ch. XVIII bears the title of 'The Cave', where the story of the 'Companions' is narrated, who are known in European tales as 'the seven sleepers'.

In this particular example, there is an implicit story behind the Farsi phrase [æshäbe] [kæhf]. The translator has 
suitably gained this fact and has tried to explicate this implicit information for the target text readers. Accordingly, he has made use of a footnote via which he has added to his translation. The target text readers are not familiar with this highly ideological and cultural fact. The companions of the cave were a group of people whose story has been mentioned in the Quran, the holy book of Muslims. As can be seen, the translator has duly explicated this fact in the footnote and has given the reference in the Quran for it. He has also referred to its common English name in Europe, the seven sleepers, so as to make it known for the readers of the target text. By doing so, the translation readers will have a better understanding of the text because the translator has given them enough clues of the background information which is implicit in the source text. In this case, the translator has truly used the lexical expansion in marginal aids by employing a footnote in his translation.

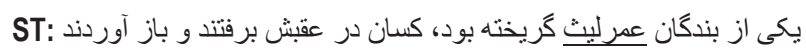
[äværdænd]

[yeki] [æz] [bændegäne] [omæreleis] [gorikhte] [bud] [kæsän] [dær] [æghæbæsh] [beræftænd] [væ] [bäz]

TT: One of the servants of Umrulais* had fled but some men, having been sent in pursuit, brought him back.

*Umrulais the second Sultan of the Saffaride dynasty reigned A. H. 267, A. D. 880.

An explanation was given by the translator regarding the personal name "عمرليث" [omæreleis] for the readers of the target text. Therefore, they can comprehend the text better and they can become familiar with the atmosphere of the source text. The lexical expansion was used here by the translator in marginal aids. Accordingly, the translator has clarified his translation and has truly mentioned in the footnote that Umrulais was a king in the Saffaride dynasty. Indeed, this fact is quite known by the source text readers and belongs to implicit background information. By explicating this implicitness, the readers of the target text will become familiar with this person. Thus, this addition here helps the process of understanding the target text.

\subsubsection{Translating geographical names}

$$
\begin{aligned}
& \text { ST: ملكى اقليمى بكيرد بادشاه } \\
& \text { همجنان در بند اقليمى دكر } \\
& \text { [molke] [eghlimi] [begiræd] [pädeshäh] } \\
& \text { [hæmchenän] [dær] [bænde] [eghlimi] [degær] }
\end{aligned}
$$

TT: If a padshah were to conquer the seven climates*

He would still in the same way covet another

*The world being, according to Moslem geography, divided into seven climates, the sense is, that if a king were to conquer the whole world, he would yet long for another to conquer.

Here, the translator has used a footnote wherein he has given an explanation about the idea of seven climates and the sense behind the words of the source text. He has properly explained about the king's greed and his excessive and rapacious desire, especially for possession of more lands in a way that this wanting to conquer more lands keeps going on and never stops in him. The translator has duly gained the implicit meaning and has tried to convey it to his readers by giving extra information via explicating part of the background information which was implicit in the source text. Accordingly, he has used expansion in marginal aids and brought intelligibility to the target text.

\subsubsection{Translating events' names}

ST: يكى از ندماى حضرت بادشاه كه در آن سال از سفر دريا آمده بود كفت من او را عيد اضحي در بصره ] [yeki] [æz] [nodæmäye] [hæzræte] [pädeshäh] [ke] [dær] [än] [säl] [æz] [sæfære] [dæryä] [ämæde] [bud] [goft] [mæn] [urä] [eyde] [æzhä] [dær] [bæsre] [didæm]

TT: One of the king's courtiers, who had that year returned from a journey, said: I have seen him at Bosrah on the Azhah festival, ${ }^{*} \ldots$

${ }^{*}$ This is the day of sacrifice in the month Zulhejjah, celebrated at Mekkah by the pilgrims. 
Here, the translator has expanded his translation by adding a footnote in which he has given an explanation about the "عيد اضحى", Azhah festival. Therefore, the target text readers can get the background knowledge behind this specific festival. Actually, this implicit meaning is known by the source text readers, but it cannot be taken for granted by the translator, since his translation readers are not familiar with this implicit information regarding this festival. And the translator has duly expressed this implicit meaning explicitly. He has properly explained that this is a special festival which is hold at Mekkah city in which the pilgrims sacrifice sheep in a special religious ceremony. Thus, this case is also a lexical expansion instance which was added to the target text in marginal aids.

\subsubsection{Translating religious terms}

ST: نشنيده اى كه هر كه خيانت ورزد بشتش از حساب بلرزد

[næshnideh] [ee] [ke] [hær] [ke] [khiyänæt] [værzæd] [poshtæsh] [æz] [hesäb] [belærzæd]

TT: Hast thou not heard the saying? "Whoever commits treachery let his hand tremble at the account."* *The resurrection is meant, when everyone will have to account for his deeds.

The translator has made his translation clear and has explained in a footnote what the author meant. In this way, the target text readers will have a better understanding of the translation. Therefore, the translator has expanded his translation by adding a footnote which is a marginal aid. In the footnote, he has truly clarified that the author, by using the account, has meant the resurrection day in which all people will be responsible for the things that they have done here in this world. Therefore, he has familiarized his readers with this belief that is common in the source language society that whenever a person is doing something bad, he should be afraid of the resurrection day. In view of that, the translator has used the lexical expansion suitably.

\subsubsection{Translating mystical proper names}

$$
\begin{aligned}
& \text { ST: كس نيايد به زير سايهء بوم كورم } \\
& \text { ور هماي از جهان شود معدوم } \\
& \text { [kæs] [næyäyæd] [be] [zire] [säyeye] [bum] } \\
& \text { [vær] [homäy] [æz] [jæhan] [shævæd] [mæedum] }
\end{aligned}
$$

\section{TT: No one goes under the shadow of an owl}

Even if the homa* should disappear from the world.

*The homa is a fabulous bird, resembling in some respects, the phoenix. The person upon whose head the shadow of it falls, when flying in the sky, is believed to be destined to occupy a throne.

Here, in this case, we can see that for translating the Farsi word "هما" [homa], the translator has borrowed the word and has used it in the target text, but he has added a footnote in his translation about it. In the footnote, he has explained about the word and the background information behind it. He has mentioned that it is a kind of bird and has referred to the existing belief in the society of the source language regarding this particular kind of bird that it is a destine maker and has the power of turning a person to a king. Therefore, he has duly and appropriately added the implicit information of the source text into the target text. And accordingly, he has used lexical expansion; moreover, he made use of it in marginal aids, here explicitly by applying a footnote. Thus, by expanding his translation, he made his translation more intelligible for the target text readers.

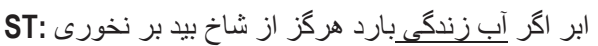

[æbr] [ægær] [äbe] [zendegi] [bäræd] [hærgez] [æz] [shäkhe] [bid] [bær] [nækhori]

TT: If a cloud should rain the water of life*

Never sip it from the branch of a willow-tree.

*the celebrated water of life, which also Alexander the Great is described to have been in search of, is said to procure the immortality, like the Amerita of the Hindus and Nectar of the Greeks.

In the above instance, it can be seen that the translator has used a footnote wherein he has given some 
explanations regarding the culturally loaded Farsi phrase [äbe] [zendegi]. He has, accordingly, expanded his translation. The translator has properly made it clear for the target text readers that this phrase refers to the famous water of life which, upon drinking it, can make the drinker immortal. It shows that the translator has duly understood that it may cause ambiguity for the readers and some of them may not be familiar with this belief, that is to say, drinking special mystic water which is immortalizer. Thus, he has made use of a footnote in his rendition. And the readers, by reading it, will gain the background information present in this case. Accordingly, the translator has brought intelligibility to the target text by using lexical expansion in marginal notes here.

Out of eighty two cases of expansion in marginal notes that were identified and analyzed in this study, eight instances have been mentioned here and the related explanations have been given. It was found that the translator, Rehatsek, used expansion techniques in his translation and gave footnotes when the unit of translation requires additional information for better clarity. It can be seen here that there are certain words or expressions that have some background information which is known by the source text readers. The additional information was rendered by the translator on the assumption that the target readers did not have access to the background information. Culture specific words such as proper names, names of festivals or events, religious terms and the rest are likely to carry some implicit information. As the given samples show, the translator has tried to convey this implicit information by using some additions in his translation, here specifically by giving footnotes. Therefore, by doing so, he has brought intelligibility to the translation. The translator's decision to add footnotes is very much in line with Nida's (1964) ideas as presented in the earlier section on theoretical framework.

\section{Conclusion}

The present research had the purpose of studying what happens to those units of translation which are related to the background of the source texts and the world and cultural knowledge of the TL readers. The research examines what translators do when faced with such units. There are always some words or expressions that are highly ideological or cultural in nature relating to the SL community that are used by the ST authors ever so simply and naturally in their writing. However, the translation of such words can be problematic due to the translation readers' lack of familiarity with those words or expressions. From the research, we found that as suggested by many translation scholars, the translator of the text Sadi's Golestan also utilized many techniques of addition.

The analysis of the translation done on the forty one stories of Sadi's Golestan, i.e. the corpus of the current study, revealed eighty two cases of the use of footnotes or marginal aids to indicate lexical expansion. This technique is what was proposed by Nida and Taber (1982) with respect to texts or aspects of text with heavily implied meaning. According to Nida and Taber, there is some information vital for grasping the message which is not immediately seen or implied in the text itself. This sort of information could just simply be related to common background knowledge which would be known to source text readers but not to target text readers. They believed that this information might not be easily captured within the translation or body of translation itself. Nonetheless, the meaning should be transferred, and it could be done using marginal notes. Nida (1964) earlier stated that there are situations where literal renditions are moderately preserved in the target text, and the requisite modifications are elucidated in marginal notes wherein the translator will give more information regarding the word(s) under question.

A noteworthy finding of this research is that the usage of expansion here is norm-governed. The findings showed that the translator has employed addition techniques to translate units of translation (in the source text) which are highly implicit. It was observed that the norm in Rehatsek's translation is to explicate using lexical expansion in marginal notes. In other words, explicitation of implicit source text information in the target text is confirmed as a norm observed by the translator. Our study has also indicated that the translator used a reader-oriented approach in his translation, as he expanded the target text taking the target readers into account while translating from one culture into another.

Through this explicitation, the reader gains knowledge that was originally possessed only by the source text reader. In turn, the target readers can get a better understanding of the text. From the analysis also, we could see that the beauty of this kind of expansion technique is that it does not embellished the translation to the point of making the meaning of the text obscure; this is so because the extra information is outside the body of the translation. Yet at the same time, the reader can easily get access to more information that helps clarify the meaning should he/she feels the need by referring to the footnotes.

Another conclusion that can be drawn from this study relates to the choice of corpus. The decision to use a known literary text like Golestan is very appropriate to study this technique of expansion. The reason is that such a text will naturally have units of translation that are culture-laden, i.e. that are heavily implied, because even though it deals with some universal values, the thoughts of the writer Sadi with respect to these values came from his experiences in life from 
his Persian background. In short, there will be many instances wherein lies the author's cultural baggage. Englishlanguage readers of the translation will presumably not share such a cultural background. Analysis of such a text enables us to do what we set out to do, that is to investigate how culture-laden words or implied meaning is accommodated.

\section{References}

Baker, M. (2004). Translation studies. In M. Baker (Ed.), Routledge encyclopedia of translation studies (pp. 277-280). New York: Routledge.

Beekman, J., \& Callow, J. (1986). Translating the word of god. Dallas: Summer Institute of Linguistics.

Davidson, R. (2009). The best Australian essays. Melbourne: Black Inc.

Ekpenyong, E. (2010). Translating and interpreting: One object, different approaches. Babel. 56(4), 328-340. doi:10.1075/ babel.56.4.03ekp

Hatim, B. \& Mason, I. (1990). Discourse and the translator, language in social life series. London: Longman.

Hirsch, G. (2011a). Between irony and humor: A pragmatic model. Pragmatics \& Cognition. 19(3), 530-561. doi:10.1075/pc.19.3.07hir

Hirsch, G. (2011b). Explicitations and other types of shifts in the translation of irony and humor. Target. 23(2), 178-205. doi:10.1075/target.23.2.03hir

Hjort-pedersen, M., \& Faber, D. (2010). Explicitation and implicitation in legal translation - a process study of trainee translators. Meta: Translators' Journal. 55(2), 237-250. doi:10.7202/044237ar

Larson, M. L. (1984). Meaning-based translation: A guide to cross language equivalence. New York: University Press of America.

Leppihalme, R. (1997). Culture bumps: An empirical approach to the translation of allusions. Clevedon: Multilingual Matters Ltd.

Minacori, P., \& Veisblat, L. (2010). Translation and technical communication: Chicken or egg?. Meta: Translators' Journal. 55(4), 752768. doi:10.7202/045689ar

Nida, E. A. (1964). Toward a science of translating: With special reference to principles and procedures involved in Bible translating. Leiden: Brill.

Nida, E. A., \& Taber, C. R. (1982). The theory and practice of translation. Leiden: Brill.

Pedersen, J. (2011). Subtitling norms for television. An exploration focusing on extralinguistic cultural references. Amesterdam /Philadelphia: John Benjamins Publishing Company.

Rehatsek, E. (2004). Gulistan: Sheikh musleh-'iddin sa'di. Tehran: Hermes Publishers.

Shiyab, S., \& Lynch, M. S. (2006). Can literary style be translated?. Babel. 52(3), 262-275.

Xiumei, X., \& Qinyan, G. (2012). Translatability vs untranslatability: A relevance-theoretic view. Babel. 58(4), 408-422. doi:10.1075 Ibabel.58.4.03xiu

Yang, L. (2010). Cultural loss in the English translation of Chinese poetry. Babel. 56(2), 168-185. doi:10.1075/babel.56.2.05liu

Yifeng Sun. (2012). (Un)translatability and cross-cultural readability. Perspectives: Studies in Translatology. 20(2), 231-247.

Zhongde, L. (2003). Ten questions on literature translation. Beijing: China Translation and Publishing Corporation. 